\title{
The Acidity of Sphagnum and its Relation to Chalk and Mineral Salts.
}

\author{
BY \\ MACGREGOR SKENE, D.Sc., \\ Lecturer on Vegetable Physiology, Aberdeen University.
}

$\mathrm{N}$ the study of the influence of the chemical nature of the soil on vegeta-
tion the question of the effect of calcium carbonate-chalk-has always occupied a prominent position. It is one of the soil constituents which can be most easily recognized and estimated; and the differences in the flora, of which its presence or absence is the cause, are frequently very striking. Lists have been compiled of plants which thrive only on chalk (calcicole), and of others which cannot live in its presence (calcifuge). Such plants may be wholly confined to the one type of soil or to the other ; or their behaviour may change with change in other external factors. Reference may be made to Nägeli's ('65) classical case of the calcicole Achillea atrata, and the calcifuge $A$. moschata. When the two occur together in the same valley, each is strictly confined to its own type of soil ; but if either occurs in absence of the other, it is non-discriminating. Another case of great interest is that of Castanea vesca, the Sweet Chestnut, which cannot grow on chalk unless an abnormally high percentage of potassium be present in, or be added to the soil (Arnold Engler, '01).

Perhaps the majority of plants written down as calcifuge belong to this indeterminate type; but there is a number of cases in which the repugnance to chalk is constant, and independent of other external factors. Of these one of the most striking examples is afforded by the genus Sphagnum, the members of which are rapidly killed off by water containing calcium carbonate.

Observation of the fact that chalk can exercise so marked an effect on vegetation has led to the attempt to find out exactly in what manner the chalk acts. Such investigation has shown that it acts in a number of quite distinct ways.

Its effect may be indirect. This seems to apply to Calluna, studied by M. C. Rayner ('13). She has shown that the presence of chalk interferes with the proper development of the mycorhiza, and promotes the growth of a bacterial sheath on the roots. This interference with the root symbiosis

[Annals of Botany, Vol. XXIX. No. CXIII. January, 1915.] 
is accompanied by symptoms of weakness on the part of the Calluna, and is apparently responsible for these.

A more direct influence must be assumed in other cases. This may be either physical or chemical.

Kraus ('11) has demonstrated very completely the effect of chalk on the water content and temperature of the soil ; the former is diminished, the latter increased as the amount of chalk present rises. And he has shown that a number of plants typically found on chalk can grow equally well on siliceous soil, if its physical properties resemble those of the chalk.

I am inclined to believe that a case illustrating this is afforded by the distribution of Helianthemum Chamaecistus in this country. The Rock Rose is generally described as a calcicole plant (see 'Types of British Vegetation', Tansley, p. I76). It is common, however, and grows well on siliceous gravels in exposed situations in the east of Scotland. In the south of England, where the choice may lie between dry warm chalk and cold wet clay, the former is chosen; where there exists a siliceous soil; which is also well drained and warm, Helianthemum can thrive thereon.

Cases in which the chalk acts chemically are also known. The fact that Castanea can grow on chalky soil when supplied with an abnormally large amount of potassium, indicates that the chalk acts by interfering with the supply of other salts through the roots. Moreover, the Chestnut grafted on the Oak can grow even on normal chalk soils-a further support of this view (see Jost, '13, p. I25). Schimper ('98) states that in some cases the failure on chalk is due to difficulty in absorbing sufficient iron, and may be obviated by watering with iron solutions.

Another extremely important effect of the chalk is that it alters the reaction of the soil, rendering it neutral or alkaline. To this is probably due its noxious effect in many cases. It will be shown that there are grounds for ascribing its fatal action on Sphagnum to this cause.

The earlier observations on Sphagnum and its relation to chalk have been collected by Paul ('08), and as most of them have been published in periodicals not readily accessible to English readers, a short summary may be of use.

Sprengel ('47) asserted that Sphagnum could not support high concentrations of any mineral substances. Sendtner ('54) was unable to grow it in chalk water, and concluded that basic substances were harmful. Milde ('61) concluded from observations in the field that Sphagmum is calcifuge. Pfeffer (' $\% 1$ ) notes that it dies in presence of chalk. Öhlmann ('98) found that it dies in a 0.05 per cent. solution of chalk, the time elapsing before death varying with the species used. To produce the same effect with calcium sulphate a solution of twice that strength was necessary, while of calcium nitrate a 0.75 per cent. solution was required. Culture solutions 
containing chalk, and tap water (at Bâle, with 0.025 per cent. chalk), were also harmful.

Weber ('00) asserts that he grew Sphagnum cymbifolium, S. fuscum, S. acutifolium, S. recurvum, S. fimbriatum, S. platyphyllum in water containing chalk with success; he even added powdered chalk to his cultures without harming them; S. recurvum fruited; only $S$. medium died with powdered chalk, though it lived in chalk water. He concludes that the chalk is harmful only in the presence of other plants, which, growing more vigorously in the chalky water, rapidly supplant the Sphagnum.

Graebner ('98, '01, '04) agrees that chalk as such is not harmful, and believes that the failure of the Sphagmum is due to too high a mineral content in general. According to Ramann ('95), Sphagnum can persist only in water containing less than $0.003-0.004$ per cent. of mineral substances.

Diiggeli ('03), as a result of experiments carried out on the moor, came to the conclusion that Sphagmum was affected adversely not only by chalk, but also by mineral salts in general. His results are not very convincing, as his mineral solutions apparently always contained chalk or magnesia, in addition to other constituents.

Haglund ('12) carried on experiments on the moor at Granarp on a large scale. Table I summarizes his results.

\section{TABLE I.}

Kilos. per Hectare of :

Lime, 6,000 .. . . died

$\begin{array}{cc}\text { Thomas phosphate, } \mathrm{I}, 000 & \text { severely injured } \\ \text { Superphosphate, } 400 \text {. } & \text { died }\end{array}$

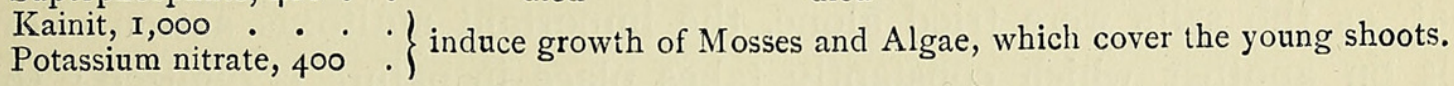

By far the most extensive investigation is that carried out by Paul himself ('06, '08). He tested many different salts and many different species of Sphagnum, and obtained important results.

In the first place he determined the concentrations of calcium carbonate necessary to kill various species of Sphagnum, and arrived at the results given in Table II.

TABLE II.

\begin{tabular}{|c|c|}
\hline Sphagnum & $\begin{array}{l}\mathrm{CaCO}_{3} \text { in mg. } \\
\text { per litre necessary } \\
\text { to cause death. }\end{array}$ \\
\hline rubellum & 77 \\
\hline papillosum & 89 \\
\hline molluscum & 89 \\
\hline medium & I 34) \\
\hline Dusenii & I 7 I \\
\hline acutifolium & 223 \\
\hline platyphyllum & 223 \\
\hline recurvum & $3^{1} 2$ \\
\hline
\end{tabular}

Station.

High moor

High moor ditches

Wood

Low moor

General 
The different species are resistant to very different degrees; the dwellers on the high-moor, where the supply of salts is normally very low, are much less resistant than those on the low moor where minerals are more abundant.

Paul then extended his observations to the effects of various salts. All the species enumerated were tested with calcium sulphate; an almost concentrated solution was employed-2 grm. per litre-and all the species grew satisfactorily in it. The other salts were tested with Sphagnum medium, a species moderately sensitive to chalk. The concentrations required to kill the Moss were as follows :

Calcium nitrate, $966 \mathrm{mg}$. per litre.

Potassium bicarbonate, 240 ; potassium carbonate, I49; sodium bicarbonate, I70; sodium carbonate, 107.

Potassium bisulphate, 720 ; potassium sulphate, 6,480 ; sodium bisulphate, 340 ; sodium sulphate, 5,725; magnesium sulphate, 2,500.

Sodium chloride, about 300 ; potassium chloride, about 375 ; calcium chloride, I,IOO.

Dipotassium phosphate, 46; monopotassium phosphate, 36 ; tripotassium phosphate, 34.5 .

Sulphuric acid, I50; nitric acid, 82.

Sodium hydroxide, 40.

From this it is evident that we cannot regard Sphagnum as being uniformly adversely affected by the high concentrations of the mineral salts applied to it. Some salts it tolerates at high, others are harmful at very low concentrations. The salts of calcium are harmless, while phosphates and alkaline salts appear to be very toxic. It must further be pointed out that, as the salts were tried alone, the important antitoxic action of one salt on another which constantly takes place in nature is omitted; this would probably raise considerably the concentration at which harm would result in a culture solution.

Paul then goes on to discuss the relation of the harmful action of chalk to the 'acidity' of the Sphagnum, and here lies the greatest interest of his work. Before discussing it, however, it will be necessary to refer to the investigations of his colleagues Baumann and Gully, and of others, on the nature of the 'acidity' of Sphagnum and peat.

In I906 Count Leiningen ('07) observed that litmus paper applied to Sphagnum turned red, and following up this, that Sphagnum plants require a considerable quantity of alkali for their neutralization-10 stems $5 \mathrm{~cm}$. long require from $\mathrm{I} \cdot 3$ to 2 c.c. of $\mathrm{N} / 10 \mathrm{NaOH}$. The degree of acidity cannot be determined by washing out the Sphagnum and titrating the wash liquid, as the acid appears to be almost insoluble; it may best be determined by shaking with excess of standard alkali and titrating back with acid. 
Baumann and Gully ('10) connected this acidity of Sphagnum with the well-known acidity of peaty soils. Peat consists largely of imperfectly decomposed Sphagnum, and it seemed probable that the acid of the peat was the acid of the Moss. They determined the acidity of the Sphagnum and of the underlying peat, and found in one case :

Sphagnum . . $0.228 \mathrm{grm}$. acid hydrogen per $100 \mathrm{grm}$.

Peat . . . 0.260 grm. acid hydrogen per 100 grm.

This relation was found to be quite general, the two agreeing closely, with the peat somewhat higher. That the two would be exactly the same was not to be anticipated; the peat contains much foreign matter, and on the other hand the plant remains in it are much altered and partly decomposed.

Baumann and Gully proceeded to investigate the nature of the acid substances. They started with an old observation of Sprengel's, confirmed by various other workers, that peat is able to decompose and render soluble tricalcium phosphate. They worked out the reaction between that compound and peat and Sphagnum. Both decompose it in precisely the same way, and to about the same extent. The reaction is very interesting, as the calcium compound is almost insoluble-according to Rindell ('99) $\mathrm{I}_{32} \mathrm{mg} . \mathrm{P}_{2} \mathrm{O}_{5}$ per litre-and it must be supposed that successive small quantities go into solution and are attacked by the organic compounds of the peat (or Sphagnum). Part of the phosphoric acid appears in the solution as such, part as monocalcium phosphate; part of the calcium is removed by the peat. The reaction consists essentially of a splitting up of the phosphate with removal of the base and liberation of the acid. The formation of the monocalcium salt may be regarded as secondary, due to action between the liberated acid and the undecomposed phosphate.

To show the extent of the solvent action we may give the following figures :

Of tricalcium phosphate with $\mathrm{I}, 200$ c.c. water, $\mathrm{I} 5^{8} \mathrm{mg} \cdot \mathrm{P}_{2} \mathrm{O}_{5}$.

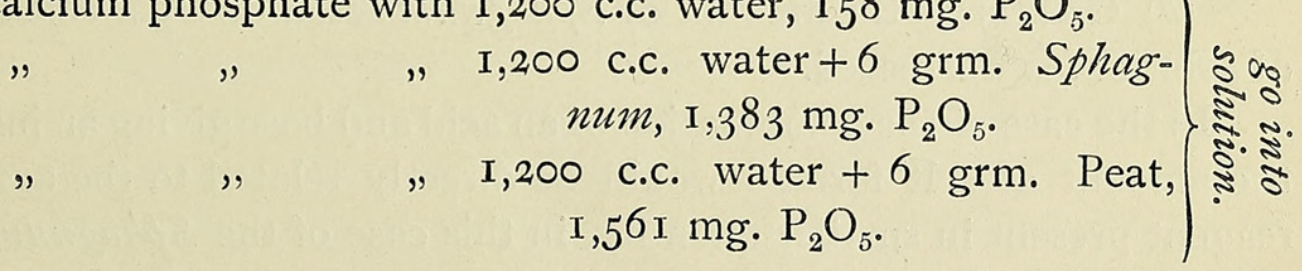

The observations were extended to other salts, and the remarkable result was obtained that, with the exception of the extremely insoluble calcium oxalate, all the salts tried were broken up with liberation of the acid of the salt. The amount of acid hydrogen liberated from the various salts tested, by 100 grm. dry peat or Sphagnum, is given in Table III. 
TABLE III.

\begin{tabular}{lcc}
\multicolumn{1}{c}{ Salt. } & Sphagnum. & Peat. \\
Sodium chloride . & 0.0122 & 0.0199 \\
Potassium sulphate : & 0.0207 & 0.0253 \\
Calcium chloride : & 0.0144 & 0.0162 \\
Ammonium sulphate & 0.0253 & 0.0300 \\
Potassium iodide & 0.0119 & 0.0120 \\
Sodium nitrate . & 0.0224 & 0.0205 \\
Sodium sulphite & 0.0778 & 0.1092 \\
Sodium formate & 0.0706 & 0.0852 \\
Sodium butyrate : & 0.0675 & 0.0836 \\
Sodium salicylate : & 0.0491 & 0.0563 \\
Ammonium acetate & not determined & \\
Calcium acetate & 0.0840 & 0.01090
\end{tabular}

It will be seen that the two substances possess the property in common, and that, while the peat is slightly more active, the two sets of figures run so closely parallel that it would seem permissible to refer the property to the possession of some common compound.

Baumann and Gully fix on the fact that the Sphagmum and peat are able to break up such salts as sodium chloride, liberating the acid and removing the base. They say that if an acid is responsible, then we must suppose that an insoluble organic acid is capable of breaking up so strong a combination as sodium chloride, producing an insoluble sodium salt, and liberating hydrochloric acid. This they consider impossible. They believe that the reaction is due to the presence of colloidal substances which adsorb the base and set free the acid. They adduce the following considerations in support of their theory:

I. The conductivity of Sphagnum ${ }^{1}$ is very low, only about I/Io of that of a solution of acetic acid having the same solvent action on tricalcium phosphate.

2. When Sphagnum acts on a salt the amount of acid liberated is, relatively to the amount of Sphagnum employed:

(a) Less as the concentration of the solution is decreased ; ${ }^{2}$

(b) Greater as the amount of Sphagnum acted on by a constant volume of solution, is decreased.

In the case of the combination of an acid and base giving an insoluble salt, the amount of salt formed would be directly related to the amount of the reagent present in smaller quantity, in this case of the Sphagnum.

3. The activity of Sphagnum decreases slowly when it is kept; this would correspond to the slow change in surface of a colloid.

1 The alternative 'peat' is implied.

2 For tricalcium phosphate aberrant results were obtained: these do not agree with the results of Tacke and Süchting, or of Fleischer (Landw. Jahrb, I883, vol. xii, p. I64) : it would seem that none of these investigators has paid sufficient attention to the complicated nature of this particular reaction, and that slight differences in method may be responsible for the discrepancies. But for chlorides a maximum absorption was found in normal solutions. 
4. Reference to Table III shows that the amounts of the acids set free from different salts are widely different. It is found that, for a series of salts with the same base, acids are liberated in the following order: (a) hydrobromic, hydriodic, hydrochloric, nitric; (b) sulphuric ; (c) acetic, the last named in largest quantity. This corresponds to the activity of the acids in various colloidal reactions.

5. As regards the bases, bivalent bases are adsorbed more actively than monovalent, potassium more than sodium.

6. It is possible to wash out a large portion of the adsorbed base with distilled water, especially if it contain carbon dioxide. By this means the original acidity of the Sphagmum may be almost completely restored.

Baumann and Gully conclude that the old 'humus acids',' to which the acidity of acid soils in general, and of peat in particular, was ascribed, are non-existent : the acidity is in reality due indirectly to the presence of negatively charged colloidal compounds; these break up any salts present in the soil, and the acid of the salt produces an acid reaction in the soil. They regard the colloids in question as being chiefly located in the hyaline cells of the Sphagnum leaf.

Since the publication of Baumann and Gully's paper a number of others have appeared supporting or criticizing their conclusions.

Czapek ('11) agrees with the authors in all their deductions. Wieler ('12) also supports the colloid hypothesis.

On the other hand, a number of chemists have attacked these views, and sought to refer the reactions to ordinary chemical processes with typical acids. The most important papers are those of Tacke and Süchting ('11), Tacke, Densch, and Arndt ('13), Rindell ('11), Odén ('12), Ehrenberg and Bahr ('13). Gully ('12) has replied to some of those criticisms. The matter is really one for the physical chemist and it is impossible to go into details, but a few of the more important points may be summarized.

Tacke and Süchting dispute some of Baumann and Gully's experimental data ; refer the phenomena with tricalcium phosphate to interaction between humus acids, phosphoric acid, and the phosphates ; find that drying to $130^{\circ} \mathrm{C}$., and consequent serious diminution of the colloidal adsorptive surface, has no influence on the amount of acid liberated; that peat can invert cane sugar, and give off hydrogen with iron-two typical acid reactions; and they can find no parallel to the reactions using other typical colloids, such as starch and gelatine. Colloid action is to be observed only in the adsorption of colloidal ferric hydroxide; all the other reactions are to be referred to the action of humus acids as such.

1 The form 'humus' is preferred to 'humous' or 'humic', as the terminations of these are associated with definite chemical constitutions. 
Rindell criticizes from the physico-chemical standpoint, and finds the reactions explicable on the assumption of a mixture of more and less soluble humus acids.

Odén and Ehrenberg and Bahr point out that it is scarcely permissible to apply fine methods, such as that of conductivity determination, to so coarse a mixture as that presented by ordinary peat. They attempt to isolate the humus acids by extraction with ammonia, precipitation with acid, and further purification.

Conductivity determinations with a preparation thus obtained led Odén to the conclusion that its combination with ammonia is of the nature of a true salt formation. He roughly determined its equivalent weight and basicity.

Ehrenberg and Bahr, with an improved preparation, confirmed these results. They also attempt to demonstrate the true chemical nature of the compound with ammonia, by observations on its thermic decomposition, and by comparing the adsorption of ammonia with that of sulphur dioxide. Their experimental results do not, however, seem capable of an interpretation on the assumption that only a simple chemical reaction is involved. They suppose that the compounds formed with bases go into solid solutions with uncombined humus acids, and so account for aberrant numerical results. This, however, seems to be an approach to the views held by Baumann and Gully. Very important is the fact that their insoluble preparation of humus acids is capable of decomposing tricalcium phosphate, so that it possesses one at least of the peculiar properties of the natural compounds.

It is clear that in the view of chemists the theory of Baumann and Gully is by no means held to be proved; but at the same time evidence as to the existence of insoluble alkaline salts of the humus acids is not forthcoming. The compounds of the artificial preparations with the alkalies are soluble; in fact on this depend the various methods for their preparation. To account for the retention of the bases in the form of such salts by the peat or Sphagnum, some sort of adsorption must be called into play. Ehrenberg and Bahr admit as much when they invoke the aid of 'solid' solutions to explain their figures; and, as a matter of fact, no one denies that the humus acids are colloids. Acids which are colloids will act both as acids and as colloids. The attempt to explain all their peculiarities on the basis of one only of these two properties is bound to lead to failure.

In what follows the terms 'acid' and 'humus acid' are employed only because they denote most conveniently the chief property of the substances in question-their responsibility, direct or indirect, for an acid reaction; this use does not imply agreement with the view that they do not act also as colloids.

For the purposes of the ecologist it is sufficient to recognize that peat contains compounds capable of breaking up salts and liberating their acids, 
and that the acid nature of peaty soil is probably largely due to the presence in it of these (mineral) acids. These compounds are already present in Sphagnum. The significance of these for the life of the Sphagnum is supposed by the authors to lie in the possibility it gives of absorbing bases from the very dilute solution in which the Bog-moss lives. They further suggest that the property is not confined to Sphagnum, but that the absorption of mineral salts by the root-hairs of the higher plants may take place in the same way.

To return to Paul's researches on the relation of Sphagnum to chalk. He suggests that the chalk saturates the acid compounds of the cell-walls, and so prevents the absorption of bases. This does not result directly in death from starvation, but it causes the plant to make an effort to replace the saturated compounds, with the result that metabolism is so much increased that death results from a sort of exhaustion.

In support of this he brings forward the fact that different Sphagna have different acidities, and that hand in hand with this variation goes the variation in repugnance to chalk, the more acid species being also the more sensitive. Table IV gives the acidity of the various species in grams of acid hydrogen per 100 grm. Sphagnum, as determined by titration with $\mathrm{N} / 4 \mathrm{NaOH}$. And along with these is given the quantity of calcium carbonate required to kill I grm. (dry wt.) of each species.

TABLE IV.

\begin{tabular}{|c|c|c|}
\hline Sphagnum & Acidity. & $\begin{array}{l}\text { Chalk fatal } \\
\text { (in mg:). }\end{array}$ \\
\hline rubellum & 0.120 & $62 \cdot 55$ \\
\hline medium & 0.104 & $59^{\circ} 93$ \\
\hline teres. & 0.102 & 172.00 \\
\hline papillosum. & $0.10 I$ & 60.02 \\
\hline molluscum. & 0.098 & $69^{\circ} 5 \mathrm{I}$ \\
\hline fuscum. & 0.096 & 68.80 \\
\hline cuspidatum & 0.093 & $75^{\circ} 18$ \\
\hline acuitifolium (moor) & 0.090 & $78 \cdot 33$ \\
\hline cymbifolium • & 0.086 & $125 \cdot 15$ \\
\hline acutifolium (wood) & 0.083 & $9^{2} \cdot 7 \mathrm{I}$ \\
\hline contortum & $0.08 \mathrm{I}$ & 工 $55^{\circ 25}$ \\
\hline Girgensohnii & 0.079 & I $2 \mathrm{I} \cdot 33$ \\
\hline recuirum. & 0.076 & I $26 \cdot 48$ \\
\hline parvifolium. & 0.074 & $185^{\circ} 47$ \\
\hline platyphyllum & 0.060 & $32 \mathrm{I} \cdot 98$ \\
\hline
\end{tabular}

The agreement between high acidity and great sensitiveness is very close ; only Sphagmum teres, with the high acidity of 0.102 , has also a great power of resistance to chalk, coming in this respect third from the end of the list. The amounts of chalk are given, not in terms of the concentration employed, but as the number of $\mathrm{mg}$. required to kill I grm. of the plant (dry wt.). If concentration is taken, the agreement, although it still holds in a general way, is not so satisfactory, as may be seen by a 
comparison with Table II. Paul prefers the former method of statement, but does not show experimentally that the toxic effect of the chalk takes place when a certain amount is supplied, rather than when a certain concentration of the solution is reached.

On the hypothesis that the presence of the humus acids is largely responsible for the supply of mineral nutrients, Paul argues that the Sphagna, which inhabit stations where the supply of salts is very low, will contain the largest quantities of these compounds. This is so: S. rubellum, the typical high moor Sphagnum, stands first, and the degree of acidity falls away in species which inhabit more favoured stations. The effect of the chalk is to neutralize the acids and render them incapable of absorbing further mineral supplies. In the high moor species, which are most dependent on their acids, this interferes more intensely with the normal metabolism of the plant, and these species are consequently the more sensitive.

The experiments to be described were commenced on the publication of Baumann and Gully's memoir, with the intention of trying over some of their results, and were subsequently extended to include some aspects of the work of Paul.

\section{Liberation of ACIDS From their Salts.}

This fundamental effect is very readily demonstrated. It is only necessary to soak a few shoots of Sphagnum rubellum for a few hours in a solution of any salt-say 5 per cent. $\mathrm{NaCl}$-and then to test with methyl orange : a strong acid reaction is always obtained. A control with distilled water always gives a negative result with methyl orange, though a slight reaction may be obtained with litmus; as this is reversed on boiling, it may be taken as due to the presence of carbon dioxide.

That the acid present in the treated salt solution is the acid of the salt employed is not so easily demonstrated. The following method is fairly conclusive. Solutions of copper chloride of $0.5 \%, 0.1 \%, 0.05 \%, 0.025 \%$, are employed; of each 100 c.c. is allowed to stand overnight with about $5 \mathrm{grm}$. (moist) of Sphagnum. Each solution is then tested with ammonium hydroxide, and the colour produced compared with that given by control portions of the original solutions. It is found that the colour given by the stronger solutions is much weakened, by the two weaker almost if not quite gone. If the chloride be tested for with silver nitrate, then the amount of the precipitate is found to be the same before and after treatment. A large amount of copper has thus been removed, while the acid radicle is present in undiminished quantity and the solution has acquired a strong acid reaction. The presence of copper in the Sphagnum may be demon- 
strated by washing free from the cuprous solution and treating with ammonia; the leaves, and especially the thicker stems, take on a marked blue-green colour.

\section{Localization of the Acid Compounds.}

Baumann and Gully express the opinion that the walls of the hyaline cells are the chief seat of the colloids, but they do not give any experimental evidence in support of this view. The attempt was made to find out whether the compounds were located in any particular position in the plant.

The leaves were carefully teased off a number of Sphagnum plants, and the leaves and leafless stems placed separately in 5 per cent. $\mathrm{NaCl}$ solution. Both gave a strong acid reaction.

Quantitative determinations show that the stem is very slightly more active than the rest of the plant. As the method employed was the same in all quantitative determinations it may be described here. It was found impossible to treat directly with sodium hydroxide, as the resulting solution was frequently too dark to admit of accurate titration. Consequently the method of estimating the acid liberated from a salt was employed. Io per cent. calcium acetate is the most advantageous salt; according to Baumann and Gully the amount of acetic acid set free is equal to 95 per cent. of the acidity of the Sphagnum, as indicated by direct treatment with sodium hydroxide. The solution obtained is almost colourless, and may be accurately titrated with phenolphthalein and hydroxide. I.5 grm. of dry Sphagnum was shaken for six hours with 100 c.c. of the solution, and the acid determined in the liquid strained off through muslin. The acid is expressed in grammes of acid hydrogen per Ioo grm. of dry Sphagnum. The figures are thus comparable with those of the former investigators which are expressed in the same way.

Two lots of Sphagnum cymbifolium were treated in this way; the one $(a)$ consisted of small branches and leaves, the other $(b)$ of carefully selected stems. The acidities were :
(a) 0.080
(b) 0.085 .

The difference is small, but it was obtained in four further experiments. The slightly greater acidity of the stems might be referred to the greater thickness of the cell-walls.

That the acid reaction is not connected with the life of the plant scarcely needs proof; it is given by plants in the fresh state, and by plants dried for several hours at temperatures of over $100^{\circ} \mathrm{C}$. From this, however, it does not follow that the reaction is due to the wall rather than to the cell contents. 
A method described by Czapek ('99) for getting rid of cell contents was tried. It consists in boiling under the reversed condenser first in ether, then in alcohol, and finally in distilled water. Such substances as fats and chlorophyll are thus removed. The treatment has no effect on the acid nature of the plant. S. acutifolium gave a strong reaction with sodium chloride after the treatment.

The cell contents, including the protoplasm, may be almost entirely removed by chloral hydrate ( 5 parts to 2 aq. dist.). S. rubellum was digested with chloral hydrate for ten days, thoroughly washed out, and then tested for acid. The results were :

\section{Untreated, 0.0947 , \\ Treated, 0.0625 .}

Examination under the microscope showed only shrivelled remains of the cell contents. The acidity is reduced to two-thirds, and this at least must be due to substances in the cell-wall. It is probable that the third, which has disappeared, is not due to cell contents, but to cell-wall also; for this must undergo some alteration under the influence of the powerful reagent.

\section{iII. Occurrence of the Acid Reaction in other Plants.}

Baumann and Gully state that several other Mosses have the same properties as Sphagnum. I tested a number of Mosses with 5 per cent. salt solution and obtained the reaction with Polytrichum strictum, P. commune, Leucobryum glaucum, Hypnum splendens, Hylocomium loreum; Fontinalis antipyretica gave a faint reaction. In addition to these, the Lichens Parmelia laevigata, Evernia furfuracea, E. prunastri, Usnea barbata, all gave a strong reaction. No reaction, on the other hand, was given by Mnium hornum, Neckera pennata, N. crispa, Hylocomium triquetrum, Leucodon sciuroides.

The reason for the negative result may be threefold. (a) The acid compounds of the moss may be saturated already. Leucodon, after washing out with $\mathrm{CO}_{2}$ water, gave a strong reaction, while the reaction of Fontinalis was increased. Weissia viridula, a chalk Moss, could be freed from adhering particles only by washing with dilute $\mathrm{HCl}$, and then water ; thereafter it gave a strong reaction. (b) Those objects which have a low acidity may be unable to liberate sufficient $\mathrm{HCl}$ from sodium chloride (an unfavourable salt) to give the reaction. The behaviour of different Sphagna illustrates this. Salt solution in which $S$. rubellum has been soaked gives a very strong reaction; if $S$. recurvum has been used the reaction is less marked, while after $S$. contortum it is slight. With contortum which has been washed it is stronger. (c) There is, in the third place, the possibility of a specific difference between the acid substances in different plants. 
Sphagnum contortum, with an acidity of 0.0276 , gives a weak but very distinct reaction with salt; while Fontinalis, with an acidity of $0.04 \mathrm{I} 4$, gives only a very faint reaction. This would seem to indicate that while $S$. contortum is more efficacious than Fontinalis in breaking up salt, the reverse is the case with calcium acetate.

The qualitative test with sodium chloride is not delicate, and all further tests were made quantitative with calcium acetate. These were not confined to the Mosses. Wieler ('13) states that the properties of Sphagnum are exhibited by the cell-walls generally of vascular plants. Confirmation of this was desirable and was obtained. The results are set out in Table V. In the cases of those plants marked $x$ a control experiment was carried out, using distilled water. In every case the water was neutral at the end of the experiment. This disposes of Arndt's suggestion that the acidity in these cases is due to soluble organic acids originally present in the plants.

\section{TABLE V.}

Plant.

Dicranum scoparium .

Fontinalis antipyretica

Neckera complanata .

Mnium hornum .

Polytrichum commune Evernia prunastri . Fagus . . . . .

Pinus . . . .

Pteris . . . .

Aira . . . . .

Calluna . . . .

Orchid air roots (sp. not known)
Parts tested.

dead leaves $x$

dead needles $x$

dead fronds $x$

dead stems and leaves $x$

dried shoots $x$

\begin{tabular}{ll}
\multicolumn{1}{c}{ Parts tested. } & Acidity. \\
& $0.054 \mathrm{I}$ \\
& $0.04 \mathrm{I} 4$ \\
& 0.0367 \\
& $0.03 \mathrm{IO}$ \\
& 0.0299 \\
& 0.0588 \\
dead leaves $\times$ & 0.0345 \\
dead needles $\times$ & 0.0230 \\
dead fronds $\times$ & 0.0230 \\
dead stems and leaves $\times$ & 0.0195 \\
dried shoots $\times$ & 0.0149 \\
nown) & 0.0172
\end{tabular}

Wieler states that cellulose as cotton-wool, and as a preparation from wood, is also acid; I tested cotton-wool and filter-paper several times with uniformly negative results. It is scarcely conceivable that they should be able to absorb bases from salts, and could they do so our entire chemical data would stand in need of revision!

The acidity of Sphagnum is on the average 0.07 , so that most of the other objects tested are less active, and lie in or below the region of the less active species of the Bog-moss.

The acid properties are widely distributed throughout the vegetable kingdom, and to them is certainly to be attributed the acid nature of humus. The action of chalk on the soil, besides the direct neutralization of acids therein, will be to saturate the acid compounds of the plant remains and so to prevent them breaking up salts in the soil solution; that is, it prevents the souring of the soil indirectly as well as directly. It need scarcely be mentioned that the presence of such compounds in the roots may have a most important bearing on the absorption of mineral nutrients. 


\section{The Variation OF ACIDity in Different Sphagna.}

Paul pointed out that the different Sphagna exhibit different degrees of acidity. It seemed possible that the differences were secondary and not primary. Were all the species of the same initial acidity, then those which live in stations where the mineral supply is low would absorb less base than those in more favourable stations, would retain more unsatisfied acid, in other words they would appear to be more acid.

I tested this theory by washing out the absorbed bases and determining the acid in the washed material. $3 \mathrm{grm}$. of dry Sphagmum was shaken with I litre of distilled water saturated with carbon dioxide from a Sparklet bottle; the water was changed thrice, and the washing lasted in all forty-eight hours. By this means about 90 per cent. of the absorbed base may be washed out. The residue was dried, and the acidity determined in the usual way. A considerable number of species was investigated, and material of each was obtained from as many localities as possible. The results are set down in Table VI.

The difference in acidity is primary; the washing out constantly increases the acidity, but almost no general levelling up between the different species takes place. On the whole they retain their relative positions, and probably the order would be still more nearly the same if a larger number of determinations were made, for the individual differences are considerable. This goes to strengthen the conclusion of Paul, that those species which live in stations poor in food-stuffs require the highest acidities in order to obtain the necessary amount of bases. Moreover, the amount of absorbed base, which is equivalent to the amount of the acid saturated, may be obtained by subtracting the secondary from the primary acidity. The results are given in the sixth column of the Table, and it is seen that the values for the various species lie quite close together. In particular the variations are scattered through the series; there is no progressive increase in the amount of saturated acid with increase in acidity; that is to say, the different species, by virtue of their different acidities, are able to hold approximately the same amount of base in reserve.

In Paul's Table the acidity seems, with one exception, to have been determined in a single sample. The differences between the species are small, frequently smaller than the differences between samples of one species as shown in my determinations. The samples of one species agree only moderately well; it is certainly impossible to get a value holding for all samples of a species, and it is scarcely permissible to take the acidity of a single sample as representative of the species as a whole.

Further, Paul's results were obtained by titration with sodium hydroxide. Rindell ('11) has remarked on the impossibility of obtaining an exact endpoint with this method; I, too, found that in many cases the solutions 
TABLE VI.

Sphagnum Acidity in grammes acid hydrogen per $100 \mathrm{grm}$. Sphagnum.

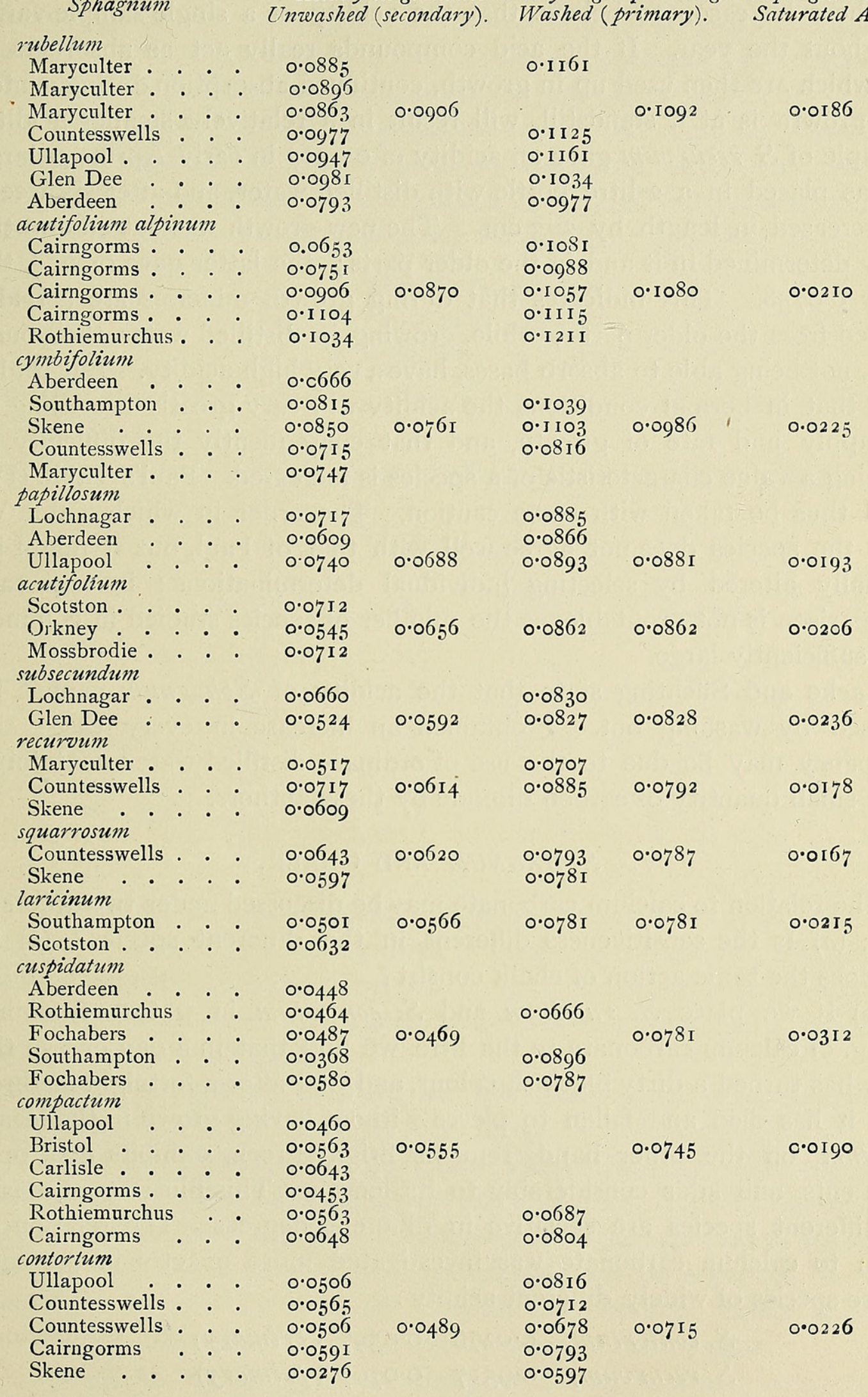


were so dark or so ruddy that any approach to accuracy was quite out of the question. With calcium acetate, on the other hand, accurate values may be almost always obtained.

There is reason to believe that the acidity of a single sample varies throughout the year. If the acid compounds really act as absorbers of salts, which are then used up in growth, continued absorption during winter, when growth is at a standstill, will result in a relatively smaller acidity. A sample of $S$. recuroum gave an acidity of $0.05 \mathrm{I} 7$ in early A pril. A large tuft was placed in a 2-litre bottle with distilled water, and after six weeks had increased in length by $2-3 \mathrm{~cm}$. The new growth was cut off and the acidity determined in it and in the older parts; the latter gave 0.0678 , the former 0.0758 . This indicates that during growth minerals are actually removed from the older parts; while, growing in distilled water, the young shoots, not being able to absorb bases, have a very high acidity. But it also shows that in normal conditions the acidity will vary greatly according to salt supply and rate of growth, and that consequently the difficulty of obtaining a value characteristic of a species is increased. Paul's Table (IV) should thus be taken with some caution. The order in which Table VI places the species does not agree well with that of Paul, but it might be materially altered by selecting individual determinations; in any case a comparison is not profitable, as the number of species studied in common is not sufficiently large.

Tacke and Suichting state that the acidity of Sphagnum cannot be increased by washing out. I obtained an increase in every case; the discrepancy may be due to the use of ordinary distilled water containing only a small quantity of carbon dioxide by these authors.

\section{SPHAGNUM AND CHALK.}

The relation to calcium carbonate may be discussed under two different heads: (a) Is the sensitiveness different in the different species? (b) In what does the toxic action of chalk consist?

(a) If we place $S$. rubellum and $S$. contortum in water containing $100 \mathrm{mg}$. of calcium carbonate to the litre, we find that in a day or two the former has turned a dirty blackish colour, and that after a fortnight or three weeks it has died and fallen to pieces without having grown in the least; contortum, on the other hand, remains bright green, exhibits geotropic movements, and adds considerably to its length. This illustrates the fact that different species are sensitive in diferent degrees. The relation of growth to calcium carbonate was investigated more exactly in the case of three species of widely different acidity:
S. contortum, 0.0276
S. recurvum, 0.0517
0.0597 (primary)
S. rubellum, 0.0863
0.0707 (primary) 
The sample of contortum used had a remarkably low acidity, only about half that usually shown by this species.

The plants were grown in 600 c.c. conical Jena glass flasks, in 300 c.c. of solution. Ten plants $5 \mathrm{~cm}$. long were grown in each flask, and every culture was duplicated, so that the results are averages for twenty plants. The cultures lasted five weeks, from the middle of March to the end of April, and were kept in an unheated room. All cultures subsequently described were carried out in precisely the same way. The results are calculated in percentages of the growth in distilled water; what that is for the various species may be seen from the following figures:
S. contortum, $4.6 \mathrm{~cm}$.
S. recurvum, $2.25 \mathrm{~cm}$.
S. rubellum, $0.75 \mathrm{~cm}$.

The small growth of rubellum makes it impossible to regard small differences in its case as significant.

The results of the cultures in chalk solutions are given in Table VII.

TABLE VII.

\begin{tabular}{cccc}
$\mathrm{CaCO}_{3}$ in mg. & \multicolumn{3}{c}{ Growth of Sphagnum } \\
per litre. & contortum. & recurvum. & rubellum. \\
& $\%$ & $\%$ & $\%$ \\
50 & 84 & 47 & 0 \\
75 & 57 & 49 & 0 \\
I00 & 44 & 51 & 0 \\
125 & 30 & 24 & 0 \\
I50 & I I & I6 & 0 \\
I75 & 4 & I 4 & 0 \\
200 & 0 & II & 0 \\
225 & 0 & 9 & 0 \\
250 & 0 & 9 & 0
\end{tabular}

From this it appears that contortum is the least sensitive, though recurvum shows a very slight growth in high concentrations. The geotropic reaction persists in contortum up to $150 \mathrm{mg}$., while in recurvum it disappears at 100; the latter is also much more severely bleached: rubellum is the most severely affected. detail.

The investigations of Paul on this point have been described in

The experiment quoted in Table VII shows: (I) that the species studied are sensitive to chalk in different degrees; $(2)$ that the more acid species are the more sensitive. Paul's thesis is thus confirmed in principle. But the very exact parallel which he finds must be criticized on several grounds. In practice it is not possible to determine either acidity or sensitiveness with the degree of accuracy which Paul suggests.

As far as can be gathered from his paper, it would seem that the samples used for acidity determinations were the same as those used for 
chalk cultures. So that, though his acidity values are not characteristic for the species, this does not invalidate, but rather enhances the value of his conclusions as to the connexion between acidity and sensitiveness. The lack of accuracy of his method of determining acidity is, however, a serious objection.

When we turn to the determination of the fatal dose of chalk, we find that it is a matter of great difficulty. This is at once evident on reading Paul's description of the behaviour of almost any species in different concentrations of chalk solution. The damage increases with concentration, but quite gradually; this applies to the decrease in the amount of growth, the discoloration, and even to the inhibition of the geotropic reaction. The effect on growth is exemplified in Table VII, and the other symptoms may be well seen in such cultures of recurvum. Even in the highest concentrations the tips may remain fresh, green, and alive. Besides the species mentioned, papillosum, subsecundum, squarrosum, and cymbifolium were examined, but only in the case of rubellum could anything like a sharp limit be obtained. The conclusion is inevitable that the designation of any particular concentration as initiating fatal damage must be largely arbitrary.

As already mentioned, Paul states his chalk as amount per Ioo grm. dry weight of Sphagnum, instead of as concentration of the solution employed. To test the validity of the assumption that it is the actual amount supplied, and not the concentration of the solution employed, that is determinative, two sets of recurvum were grown, one in 2,000 c.c., the other in 200 ; the chalk present in each was the same-200 mg., so that only the concentration was different. The first set showed a growth of 37 per cent., a strong geotropic curvature, and a fairly healthy colour ; the second did not grow at all, showed no curvature, and was quite dead. From this it follows that it is the high concentration that is effective.

Paul shows that even in the case of rubellum the amount of chalk supplied must be sufficient to neutralize the acid compounds before damage sets in. Were such small quantities of solution employed that the amount of chalk therein was not sufficient to neutralize the Sphagmum employed, then amount would enter as a factor. When, as in my experiments, an excess is present even in the dilute solutions, then only concentration will come into play. Paul's paper gives no clue as to the amount of solution he employed.

That contortum and recurvum are sensitive to different degrees is clear, but in the Acidity Table no less than four species lie between these two; it will be understood that to demonstrate a difference in sensitiveness between neighbouring members of that series of six would be a matter of very considerable difficulty.

We must conclude that while the correlation which Paul finds can be 
demonstrated for species of markedly different acidities, it is not possible in practice to follow it out in fine detail.

(b) The theory that the toxic action of chalk is due to saturation of the Sphagnum acids, and subsequent derangement in metabolism, does not appear probable in view of the various experiments and observations quoted. If the saturation acts directly, it is difficult to see why high concentrations should kill the highly acid species and not those with low acidity. And it is difficult to conceive the mechanism of an indirect action. The Sphagnum cannot feel the want of fresh absorbed base at once, for it is capable of living and growing in distilled water for a long time at the expense of previously absorbed base. A Sphagnum supplied with a fatal amount of chalk dies promptly, and shows no sign of attempting to manufacture a fresh quantity of acid compound by temporarily increased growth.

The most powerful argument against this view is supplied by the behaviour of Sphagnum to salts. These too are capable of saturating the acids, but despite this many of them are supported in high concentrations, although they may be no better nutrients than calcium carbonate. Calcium sulphate was supported in all the species Paul tested, in concentrations up to $2,000 \mathrm{mg}$. per litre $\left(=\mathrm{I}, 400 \mathrm{mg} \cdot \mathrm{CaCO}_{3}\right)$. The case of calcium chloride is conclusive; it is no better as a food-stuff than the carbonate, and it is supported by $S$. medium up to $966 \mathrm{mg}$. per litre $\left(=880 \mathrm{mg} \cdot \mathrm{CaCO}_{3}\right)$.

If we look for a more natural explanation, the most probable seems to be that it is by altering the reaction of the solution that the carbonate acts. Sphagnum can grow best in an acid medium, which it cannot obtain in the presence of chalk. The ability to withstand high concentrations of chalk would then be an ability to withstand strong alkaline reactions. The behaviour of Sphagnum to acids and alkalies provides a means to test this hypothesis.

The acids and alkalies chosen-hydrochloric and citric acids, and sodium hydroxide and sodium bicarbonate-could scarcely stimulate growth by supplying mineral nutrients. The results are given in Tables VIII and IX.

\section{TABLE VIII.}

\begin{tabular}{|c|c|c|c|c|c|c|}
\hline \multirow{2}{*}{$\begin{array}{c}\text { Concentration } \\
\text { of alkali. }\end{array}$} & \multicolumn{2}{|c|}{ contortum. } & \multicolumn{2}{|c|}{$\begin{array}{l}\text { Growth of Sphagnum } \\
\text { recurvum. }\end{array}$} & \multicolumn{2}{|c|}{ rubellum. } \\
\hline & $\mathrm{NaOH}$. & $\mathrm{NaHCO}_{3}$. & $\mathrm{NaOH}$ & $\mathrm{NaHCO}_{3}$. & $\mathrm{NaOH}$. & $\mathrm{NaHCO}_{3}$. \\
\hline $\mathrm{N} / 250$ & ${ }_{7}$ & $\begin{array}{l}\% \\
7\end{array}$ & $\begin{array}{c}\% \\
0\end{array}$ & $\begin{array}{l}\% \\
13\end{array}$ & $\%$ & $\%$ \\
\hline $\mathrm{N} / 500$ & 85 & 62 & o & 15 & o & o \\
\hline $\mathrm{N} / 75^{\circ}$ & $9^{\circ}$ & 70 & o & $1 \ddot{5}$ & $\circ$ & \\
\hline $\mathrm{N} / 1000^{\circ}$ & 63 & 66 & o & 20 & o & 6 \\
\hline $\mathrm{N} / 2000$ & 70 & 64 & 62 & $3^{8}$ & 20 & 26 \\
\hline $\mathrm{N} / 3000$ & 100 & 88 & 70 & 70 & 26 & 33 \\
\hline $\mathrm{N} / 5000$ & 80 & 93 & 93 & 73 & I06 & II 6 \\
\hline
\end{tabular}


TABLE IX.

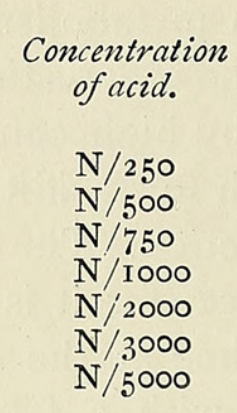

\begin{tabular}{|c|c|c|c|c|c|}
\hline \multicolumn{6}{|c|}{ Growth of Sphagnum } \\
\hline $\begin{array}{l}\text { conto } \\
\mathrm{HCl} \text {. }\end{array}$ & tum. & $\begin{array}{l}\text { recu } \\
\mathrm{HCl} \text {. }\end{array}$ & rum. & rube & $\begin{array}{ll}\text { llum. } & \text { HCit. }\end{array}$ \\
\hline$\%$ & $\%$ & $\%$ & $\%$ & $\%$ & $\%$ \\
\hline 0 & 49 & 0 & 93 & 0 & 80 \\
\hline I 3 & 100 & 40 & 107 & o & 87 \\
\hline $3^{2}$ & 124 & $5 \mathrm{I}$ & $\mathrm{I}_{4} 2$ & 33 & 93 \\
\hline 92 & 124 & 64 & I 27 & 85 & 100 \\
\hline I 18 & II 3 & II 8 & II 8 & 103 & I06 \\
\hline I 36 & $I_{42}$ & I 3 I & I 47 & 127 & II 4 \\
\hline I 23 & 122 & I3 I & I 47 & I 55 & 109 \\
\hline
\end{tabular}

The results are a little irregular. We may, however, draw from them the following conclusions :

(a) contortum is but little injured by hydroxide of $\mathrm{N} / 500$ or less, for recurvum the concentration is $\mathrm{N} / 3,000$, and for rubellum $\mathrm{N} / 5,000$. The same holds good for the bicarbonate, except that it is rather more favourable than the hydroxide for recurvum. These alkalies act, then, in precisely the same manner as does chalk.

(b) For all three species hydrochloric acid ceases to be harmful at between $\mathrm{N} / \mathrm{I}, 000$ and $\mathrm{N} / 2,000$, citric at $\mathrm{N} / 500$. At lower concentrations both acids exercise a very decided stimulating effect on growth.

Taken alone, the results with alkalies may be interpreted in the sense of Paul's hypothesis - in fact, he does quote experiments with alkalies in its support. But in conjunction with the stimulatory effects of acids in low concentrations, they afford good grounds for assuming that the harmful effect of chalk and the alkalies lies in the fact that they deprive the Sphagmum of the acid reaction which is beneficial to it.

The method by which Sphagnum obtains its supply of nutrient bases entails the liberation of the acids of the salts concerned; consequently the Sphagna are normally bathed in an acid solution. The reaction was at first an accidental accompaniment of another process, but it has now become a necessity for the Moss. Those species living in stations where the salts (and consequently usually also chalk) are scarce require a large quantity of acid compounds; they are doubly secured from ever encountering an alkaline reaction. Those inhabiting the more favoured low moors, both because they are less acid, and because chalk is more abundant in their environment, have more chance of being subjected to the influence of a neutral or alkaline medium. It naturally follows that the former are more sensitive than the latter. In some such way can we account for the connexion between acidity and sensitiveness. Be that as it may, it would seem that the preference of Sphagmum is for an acid reaction, its repugnance, in the case of chalk as in other cases, for an alkaline one. 


\section{SPHAGNUM AND Mineral SOLUTIONS.}

It remains to consider the fairly widespread opinion that the Bog-mosses are sensitive to high concentrations, as such, of mineral solutions. From experiments quoted it is clear that some salts are much more dangerous than others, but the effect of a complete culture solution has not been tried. In making up a solution, the first difficulty that meets one is the phosphate supply. The extreme toxicity of phosphates has been pointed out by Paul, and emphasized by Haglund. I tried a series of ten phosphates on S. contortum, and found it considerably more resistant than the species (medium) tested by Paul. It withstood at least $50 \mathrm{mg}$. of all of them. Further, the toxicity was considerably lessened by the presence of calcium sulphate. In its presence $250 \mathrm{mg}$. were resisted. In view of this experience a solution of the following constitution was employed:

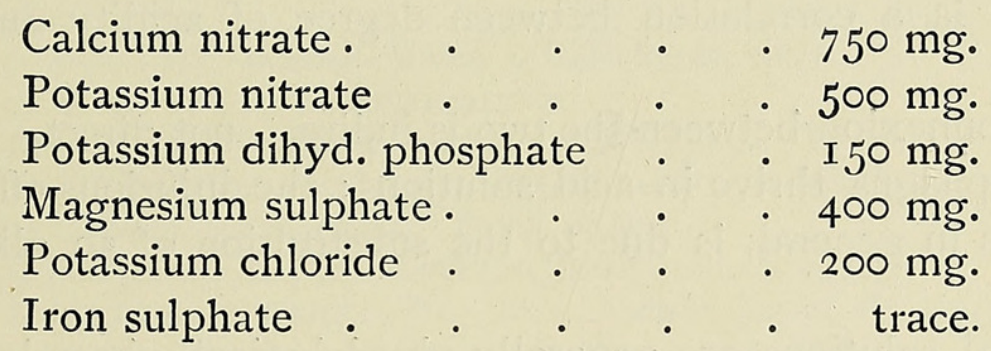

The reaction is acid; but a second set of cultures was tried with the same solution to which just sufficient sodium hydroxide had been added to neutralize the acid. The concentrations used and the results are given in Table X.

\section{TABLE $X$.}

\begin{tabular}{|c|c|c|c|c|c|c|}
\hline \multirow{3}{*}{$\begin{array}{c}\text { Concentration } \\
\% \\
0.0 \mathrm{I}\end{array}$} & \multicolumn{6}{|c|}{ Growth of Sphagnum } \\
\hline & $\begin{array}{l}\text { conto } \\
\text { acid. }\end{array}$ & tum. & $\begin{array}{l}\text { recur } \\
\text { acid. }\end{array}$ & alk. & $\begin{array}{l}\text { rubel } \\
\text { acid. }\end{array}$ & \\
\hline & $\begin{array}{c}\% \\
\text { I I } 8\end{array}$ & $\begin{array}{c}\% \\
120\end{array}$ & $\begin{array}{c}\% \\
\text { I } 70\end{array}$ & $\begin{array}{l}\% \\
142\end{array}$ & $\begin{array}{l}\% \\
66\end{array}$ & \\
\hline 0.05 & I 38 & 125 & 147 & II 8 & 76 & \\
\hline 0.1 & I 35 & 95 & I 49 & 90 & 73 & \\
\hline 0.25 & II 2 & 93 & IIO & 35 & $5 \mathrm{I}$ & \\
\hline 0.5 & 60 & $5^{8}$ & 70 & 49 & 35 & \\
\hline
\end{tabular}

rubellum is slightly harmed by even the most dilute acid solutions, and can evidently not support even low salt concentrations. The other two, however, thrive best in stronger solutions. contortum is best in $0.05^{-0.1}$, recurvum in $0.0 \mathrm{I}$, though it shows a vigorous growth in the next higher concentrations. When the solution is originally alkaline, the favourable concentrations are lowered in all cases. This again demonstrates very clearly the effect of the alkaline reaction. Although the two more resistant species grow well in solutions of a salt content comparable to that offered in water culture to flowering plants, it does not follow that these conditions will be equally favourable in nature. In my cultures it was seen that after 
about two months a vigorous growth of Algae appeared; in three months the Algae completely covered the Sphagna, so that a continued healthy growth of these was impossible. Haglund, as already stated, made similar observations, and the same thing may be seen frequently in the field with Sphagna growing in ditches.

These experiments yield no data as to the nutrient value of the salts employed. They only show that the less acid Sphagna flourish in quite high concentrations of mineral solutions in artificial cultures.

\section{CONCLUSIONS.}

In addition to the criticism and elucidation of various other points, the chief conclusions which may be drawn from the preceding pages are:

I. There is a variation in acidity and in sensitiveness to chalk between the different species of Sphagnum.

2. There is a correlation between degree of acidity and degree of sensitiveness.

3. The connexion between the two is indirect, not direct.

4. The Sphagna thrive in acid solutions: the injurious effect of chalk, and of alkalies in general, is due to the substitution of an alkaline for an acid reaction.

5. Mineral solutions are generally physiologically harmless, but may be ecologically harmful.

6. The Sphagna do actually utilize in growth bases held absorbed by the acid compounds of the cell-walls.

The subject was brought to my notice by Professor Dr. Ludwig Jost, of Strasburg, and to him my most sincere thanks are due for this, and for advice and criticism. To Professor J. W. H. Trail, F.R.S., of Aberdeen, I am indebted for literature references, and to various friends for help, especially in obtaining material.

Part of the expense was defrayed by a grant from the Carnegie Trustees, to whom I wish to express my obligations.

\section{LITERATURE.}

1. Baumann, A., and Gully, E. ('10): Mitteil. der kön. bayr. Moorkulturanstalt, Heft 4 .

2. CzapeK, F. ('99): Flora, vol. lxxxvi, p. $3 \mathbf{I} 6$. ('11) : Zeitschr. f. Bot., vol. iii, p. 28.

4. DÜGGELI, M. ('03): Vierteljahrschrift der naturf. Ges. in Zürich, vol, xlviii.

5. Ehrenberg, P., and BAHr, F. ('13) : Journ. f. Landwirt., vol. 1xi, p. $42 \%$.

6. Engler, Arnold ('01): Ber. schweiz. bot. Ges., vol. xi, p. 23. 
7. Graebner, P. ('98) : Arch. der Brandenburgia, vol. iv.

8. ('01): Die Heide Norddeutschlands. Leipzig.

9. ('04): Handbuch der Heidekultur. Leipzig.

10. Gully, E. ('12) : Mitteil. der kön. bayr. Moorkulturanstalt, Heft 5.

11. Haglund ('12): Svenska bot. Tids.

12. Jost, L. ('13) : Pflanzenphysiologie, 3. Aufl.

13. KraUS, Gregor ('11): Boden und Klima. Fischer, Jena.

14. Leiningen, W. ('07) : Naturwiss. Zeitschr. f. Forst- u. Landwirtsch., 1907.

15. Milde, J. ('61) : Bot. Zeit., vol. xix, p. 3I Suppl.

16. NÄGELI ('65): Sitzber. Münch. bot. Mitteil., vol. ii, p. I.

17. Odén, Sven ('12): Ber. d. deutsch. chem. Ges., vol. xlv, part I, p. 65 I.

18. Öhlmann, V. ('98): Diss., Freiburg.

19. PAUL, H. ('06): Ber. d. deutsch. bot. Ges., vol. xxiv.

20. ('08) : Mitteil. d. kön. bayr. Moorkulturanstalt, Heft 2, p. 63 .

21. Pfeffer, W. (' 7 I) : Bryogeographische Studien aus den rhätischen Alpen. Neue Denkschriften der allg. schweiz. Ges. f. d. gesamt. Naturwiss. Zürich.

22. Ramann, A. ('95): Neues Jahrb. f. Mineralogie, Beil., vol, x.

23. Rayner, M. Chevely ('13): New Phyt., vol. xii, p. 59.

24. Rindell, Arthur ('99): Untersuchungen über die Löslichkeit einiger Kalkphosphate. Helsingfors.

25. ('11): Internat. Mitteil. f. Bodenkunde, vol. i.

26. Schimper, A. F. W. ('98): Pflanzengeographie.

27. Sendtner, O. ('54): Die Vegetationsverhältnisse Südbayerns. München.

28. Sprengel, C. ('47): Notes on Lesquereux, Leo. Untersuchungen über die Torfmoose. Deutsche Übersetz. von Lengerke. Berlin, I 847 .

29. TACKe, B., u. Sǘchting, H. ('11): Landwirt. Jahrb., vol. xli, p. 7 I 7.

30. Tacke, B., Densch, A., u. ARndt, Th. ('13): Landwirt. Jahrb., vol. xlv, p. I95.

31. Weber, C. A. ('00) : Jahresber. d. Männer vom Morgenstern, Heft 3.

32. Wieler, A. ('12) : Ber. d. deutsch. bot. Ges., vol. xxx, p. 394. 


\section{$2 \mathrm{BHL}$ Biodiversity Heritage Library}

Skene, Macgregor. 1915. "The acidity of sphagnum and its relation to chalk and mineral salts." Annals of botany 29, 65-87. https://doi.org/10.1093/oxfordjournals.aob.a089538.

View This Item Online: https://www.biodiversitylibrary.org/item/243629

DOI: https://doi.org/10.1093/oxfordjournals.aob.a089538

Permalink: https://www.biodiversitylibrary.org/partpdf/320051

\section{Holding Institution}

Smithsonian Libraries

\section{Sponsored by}

Biodiversity Heritage Library

\section{Copyright \& Reuse}

Copyright Status: Not in copyright. The BHL knows of no copyright restrictions on this item.

This document was created from content at the Biodiversity Heritage Library, the world's largest open access digital library for biodiversity literature and archives. Visit BHL at https://www.biodiversitylibrary.org. 